\title{
TANULMÁNYOK
}

KISS ZOLTÁN ${ }^{1}-$ SZABÓ ESZTER $^{2}$

\section{Tanítójelöltek testneveléssel kapcsolatos szemlélete egy összehasonlító vizsgálat tükrében}

A tanitóként dolgozó pedagógusok testnevelés tantárggyal kapcsolatos attitüdje meghatározhatja, befolyásolhatja a tantárgy oktatásának színvonalát. Ennek okán több szempontból közelítve vizsgáltuk meg a leendö tanitók testnevelés tantárgyhoz való viszonyulását, amely direkt és indirekt módon is hatást gyakorolhat majd munkájukra, amennyiben a pályán való elhelyezkedés mellett döntenének.

A mintába bekerülő hallgatók válaszait többek között a nemek és a müveltségterületek vonatkozásában is összehasonlítottuk. A nemek véleménye nagyfokú hasonlóságot, a müveltségterületek összehasonlitása viszont már nagyobb eltéréseket mutatott, leginkább a testnevelés müveltségterületes hallgatók esetében.

\section{Bevezetés}

Az iskolai tantárgyak közül talán leginkább a testnevelést jellemzi az emocionális hatások folyamatos jelenléte, amely a kisiskolás korosztály esetében még hatványozottabban is igaz. Amennyiben a testnevelés tanórát vezető pedagógus képes úgy irányítani, hogy a gyermekek részéről döntően pozitív legyen a tanórákon megélt szituációk többsége, akkor az egyértelmüen kedvező irányba mozdíthatja el a tanulók mozgással kapcsolatos attitüdjét. Amennyiben az attitűd mértéke megfelelően erőteljes, akkor az hatással lehet az iskola falain kívüli tevékenységekre is, és akár egy élethosszig is meghatározhatja az egyén mozgással kapcsolatos szokásait, ideális esetben a mindennapokba is beépülve. Mindezzel nagyjából meghatároztuk a testnevelés tantárgy talán legfontosabb célját, amely egyebek mellett azért is rendkívül lényeges kérdés, mert a mindenkori ifjúság későbbi életminőségét is nagyban befolyásolhatja.

Általános vélekedés, hogy a testnevelés tantárgy jellemzően a kedvelt tantárgyak közé tartozik, amit több kutatás eredménye is alátámaszt (Földesiné, 1982; Jankovics, 1990; Báthory,

\footnotetext{
${ }^{1}$ főiskolai docens, Eötvös József Főiskola Pedagógusképző Intézet, kiss.zoltan@ejf.hu / egyetemi adjunktus, Kaposvári Egyetem Sport Iroda és Létesítmény Központ, kiss.zoltan@ke.hu

2 egyetemi adjunktus, Kaposvári Egyetem Sport Iroda és Létesítmény Központ, szabo.eszter@ke.hu
} 
2000; Oláh és Makszin 2005). Hamar és Karsai (2008) a vizsgálatukban hasonló következtetésre jutottak, de azt is megállapították, hogy 15-16 éves életkortól, elsősorban a lányoknál, a pozitív attitüd faktorban a testnevelés iránti pozitív érzelmi telítettség drasztikusan csökken. Báthory (1989) vizsgálati eredményei alapján szintén arról számolt be, hogy még a legkedveltebb tantárgy, a testnevelés kötődési számaiban is csökkenés figyelhető meg a 4. és a 12. évfolyamok között. Gombocz (1999) egyik tanulmányában pedig azt közölte, hogy adataik szerint a testnevelés népszerüsége már egyáltalán nem olyan fényes, mint korábban, amit jól bizonyít a tantárgy és az iskolai sport iránti lelkesedés jelentős visszaesése. A lehetséges okok között említi egyrészről az autoriter tanári stílust, másrészről pedig a fiatalok korábbról szinte ismeretlen passzivitását, akaratnélküliségét, közömbösségét.

Valóban, gyakorta hallani olyan hangokat, hogy a fiatalságot egyre nehezebb rábírni a fizikai aktivitásra. Már nem elég a régi, egykor még müködő módszerek használata, mert az ifjúság állandóan újabb és újabb impulzusokat igényel, ezért elengedhetetlenül szükséges az oktatásba újszerü és korszerü elemeket bevonni annak érdekében, hogy a tanulókban fenntartható legyen az érdeklődés. Ez utóbbi megállapítást némileg árnyalja, hogy az újszerü megközelítések alkalmazása nehézségekkel is járhat, amit jól példáz a relaxáció bevezetésének problematikája (Domokos, 2015).

Mindebből következik, hogy nincs könnyű feladatuk azoknak a pedagógusoknak, akik testnevelést tanítanak. Különösen igaz ez az alsó tagozaton, hiszen a 6-10 éves korosztály személyiségfejlesztése, a motorikus képességek fejlesztése ebben az időszakban kifejezetten meghatározó. Ez a munka ideális esetben szakmai elhivatottságot és az adott területtel kapcsolatos jelen esetben a testnevelés iránti -kedvező attitüdöt igényel. Ezt segítheti a sporttal kapcsolatos előélet, de nem abszolút feltétele, mert legalább ennyire fontos a tantárgy jelentőségével kapcsolatban a személyiségformálásra gyakorolt óriási szerepének belátása.

Kis (1989) szerint érzelmi hatások nélkül elképzelhetetlen a testnevelés és sport területén az attitüdök kialakítása.

A tanulók tantárggyal kapcsolatos érzéseit viszont tanítói oldalról nagymértékben befolyásolhatja a testneveléssel és sporttal kapcsolatos pozitív viszonyulás. Ennek okán fontosnak tartjuk, hogy a leendő tanítóknak megismerjük a tantárggyal kapcsolatos szemléletét. 


\section{Célkitüzés}

A kutatás általános célja az volt, hogy feltárjuk a tanító szakos hallgatók testnevelés tantárgy iránti attitüdjének jellemzői jegyeit:

- a tantárgy megítélésével, szerepével, feladataival;

- a tantárgy és a nevelés kapcsolatával

- és a tanítók tevékenységével kapcsolatban.

Elhatároztuk, hogy a rendelkezésre álló mintán belül összehasonlításokat is fogunk végezni a nemek és a müveltégi területek vonatkozásában.

\section{Hipotézis}

Feltételeztük, hogy a testnevelés tantárggyal kapcsolatos attitüdök a vizsgált csoportok összehasonlítása során a nemek esetében nem, viszont a testnevelés és nem testnevelés müveltségterületesek között jelentős eltéréseket mutatnak.

\section{A vizsgálat mintája és módszere}

A kérdőíves kutatásunkat tanító szakos hallgatók körében végeztük, amelynek lezárására 2013ban került sor.

A tanítóképző intézmények kiválasztásakor figyelembe vettük, hogy a vizsgálatban egyaránt szerepeljen a fővárosban, illetve különböző megyeszékhelyeken és kisebb városokban található intézmény. Az intézmények kiválasztásánál a nagyobb megbízhatóság miatt a személyes ismeretségekre is hagyatkoztunk, hogy a kérdőívek kitöltése és a visszaküldés lehetőség szerint zökkenőmentesen haladjon.

A kérdöívek visszaérkezését követően végül az alábbi hat intézmény hallgatói kerültek be a mintába:

- Eötvös József Főiskola Neveléstudományi Kar, Pedagógusképző Intézet, Baja;

- Eötvös Lóránd Tudományegyetem Tanító- és Óvóképző Kar, Budapest;

- Kaposvári Egyetem Pedagógiai Kar, Kaposvár;

- Nyugat-magyarországi Egyetem Mủvészeti Nevelés- és Sporttudományi Kar, Tanítóképző Intézet, Szombathely; 
- Szegedi Tudományegyetem Juhász Gyula Pedagógusképző Kar, Tanító- és Óvóképző Intézet; Szeged;

- Szent István Egyetem Alkalmazott Bölcsészeti és Pedagógiai Kar, Jászberény.

A vizsgálatot összesen 676 kitöltött kérdőív segítette (1. táblázat). A hallgatók nemek szerinti megoszlása: $\mathrm{N}=574$ fö (84,9 \%) nő, $\mathrm{N}=102$ fö (15,1\%) férfi.

\begin{tabular}{|c|c|c|c|c|c|c|c|c|c|}
\hline & \multicolumn{2}{|c|}{ I. évf. } & \multicolumn{2}{|c|}{ II. évf. } & \multicolumn{2}{|c|}{ III. évf. } & \multicolumn{2}{|c|}{ IV. évf. } & \\
\hline & nö & férfi & nö & férfi & nö & férfi & nö & férfi & \\
\hline EJF & 4 & - & 16 & 2 & 3 & 3 & 21 & 1 & 50 \\
\hline $\begin{array}{c}\text { ELTE- } \\
\text { TÓK }\end{array}$ & 15 & 1 & 72 & 7 & 20 & 2 & 13 & - & 130 \\
\hline KE-PK & 88 & 23 & 26 & 11 & 26 & 7 & 60 & 13 & 254 \\
\hline $\begin{array}{l}\text { NYME- } \\
\text { MNSK }\end{array}$ & 19 & 2 & 11 & - & 18 & 1 & 20 & 6 & 77 \\
\hline $\begin{array}{c}\text { SZIE- } \\
\text { ABK }\end{array}$ & - & - & 12 & 1 & 38 & 6 & 1 & - & 58 \\
\hline $\begin{array}{c}\text { SZTE- } \\
\text { JGYPK }\end{array}$ & 24 & 9 & 29 & 2 & 15 & 4 & 23 & 1 & 107 \\
\hline & 150 & 35 & 166 & 23 & 120 & 23 & 138 & 21 & \\
\hline & \multicolumn{2}{|c|}{185} & \multicolumn{2}{|c|}{189} & \multicolumn{2}{|c|}{143} & \multicolumn{2}{|c|}{159} & \\
\hline
\end{tabular}

1. táblázat. A hallgatók ( $N=676)$ intézményenkénti, évfolyamonkénti és nemenkénti bontásban

A kérdőív 21 állítást tartalmazott, amelyekre ötfokozatú Likert-típusú attitűdskálán kellett az egyetértés vagy az egyet nem értés szintjét bejelölni. Az ötös skálán a „,határozott egyetértés” az egyes, az „egyetértés” a kettes, a „,nem tudom” a hármas, az „,egyet nem értés” a négyes, a „,határozott egyet nem értés” pedig az ötös értéket jelentette. A pozitív töltettel megfogalmazott állításoknál az alacsony, a negatív töltetüeknél a magasabb átlageredményeket számítottuk kedvező válasznak. A teljes mintát több szempont szerint is összehasonlítottuk, de jelen tanulmányban csak a nemek, illetve a testnevelés és nem testnevelés müveltségterületek közötti összevetést ismertetjük.

Az adatok feldolgozása és elemzése folyamán leíró és matematikai statisztikai eljárásokat végeztünk, melynek során Microsoft Excel táblázatkezelő és SPSS (Statistical Package for Social Science) szoftvereket használtunk. 
A leíró statisztikai elemzésekben átlagot, szórást, gyakoriságot és relatív gyakoriságot számoltunk. A matematikai statisztika során t-próba vizsgálatokat végeztünk. A vizsgálatban a szignifikancia szintet 5\%-ban $(\mathrm{p}=0,05)$ jelöltük meg.

\section{Eredmények}

A kutatás során kapott eredmények közül csak azok ismertetésére szorítkozunk, amelyek a leginkább szolgálják a nemek, illetve a testnevelés és nem testnevelés műveltségterületek szerinti véleménykülönbségek ismertetését.

\section{A hallgatók véleményének nemenkénti összehasonlítása}

A kérdőívben található 21 állítás közül mindössze háromnál találtunk jelentősebb véleménybeli eltérést (2. táblázat).

A férfi hallgatók átlaga $(1,44)$ és a női hallgatók átlaga $(1,68)$ között szignifikáns $(\mathrm{t}=-2,749$; p=0,007) különbséget tapasztaltunk a tantárgy fontosságának megítélését érintő kérdésben. A férfiak attitüdje tehát pozitívabb, jobban kiállnak a testnevelés tantárgy értékei mellett, amelynek lehetséges okai között említhető, hogy az általános és a középiskolákban egyaránt nagyobb a tantárgy kedveltsége a fiúk körében. Az eredményt valamelyest talán az is befolyásolhatta, hogy a testnevelés müveltségterületesek körében eleve nagyobb arányban fordulnak elő férfiak, mint a többi müveltségterületen.

A másik jelentősebb eltérést azzal a felvetéssel kapcsolatban tapasztaltuk, hogy az eszközhiány milyen mértékben lehet befolyásoló tényező a testnevelés alapelveinek és céljainak megvalósításában. A testnevelés tanításában sokszor adódhat olyan helyzet, hogy nincs megfelelő vagy elég eszköz egy adott feladathoz, és ilyenkor szükség lehet a kreativitásra, az improvizációra. A nemek közti összehasonlításban a férfi hallgatók inkább azon a véleményen voltak (férfiak átlaga: 2,44; nők átlaga: 2,70; $\mathrm{t}=-2,06 ; \mathrm{p}=0,041$ ), hogy a tantárgy feladatait, a munkafolyamatot nem akadályozhatja az eszközhiány, a felszerelés hiánya.

A testnevelés jövőre vonatkozó melléktárgyi szerepének negatív töltetű állításával kapcsolatban a teljes minta a közepesnél kicsit jobb eredményt produkált (átlag: 2,55), a különböző összehasonlítások esetén pedig csak a nemek között találtunk szignifikáns véleménykülönbséget, ugyanis a női hallgatók pozitívabban ítélik meg a tantárgy jövőbeni helyzetét $(\mathrm{t}=-2,14$; $\mathrm{p}=0,034)$. 


\begin{tabular}{|l|c|c|c|}
\hline & $\begin{array}{c}\text { nők át- } \\
\text { laga }\end{array}$ & $\begin{array}{c}\text { férfiak } \\
\text { átlaga }\end{array}$ & szign. \\
\hline A tantárgy egyenrangúsága, fontossága & 1,68 & 1,44 & $\begin{array}{c}\mathrm{t}=-2,749 ; \\
\mathrm{p}=0,007\end{array}$ \\
\hline $\begin{array}{l}\text { Az eszközhiány és a testnevelés alapelveinek } \\
\text { és céljainak kapcsolata }\end{array}$ & 2,70 & 2,44 & $\begin{array}{c}\mathrm{t}=-2,06 ; \\
\mathrm{p}=0,041\end{array}$ \\
\hline $\begin{array}{l}\text { A testnevelés jövőre vonatkozó melléktárgyi } \\
\text { szerepe }\end{array}$ & 2,58 & 2,36 & $\begin{array}{c}\mathrm{t}=-2,14 ; \\
\mathrm{p}=0,034\end{array}$ \\
\hline
\end{tabular}

\section{2. táblázat. A hallgatói véleménykülönbségek bemutatása nemenkénti összehasonlításban}

A testnevelés és nem testnevelés müveltségterületes hallgatók véleményének összehasonlitása A testnevelés mủveltségterületes hallgatók véleménye több témakörben is szignifikáns eltérést mutatott a többi műveltségterület hallgatóihoz képest. A tanulmány terjedelmének maximalizálása miatt a teljesség igénye nélkül néhányat ismertetünk csak az alábbiakban.

A tantárgy fontosságával, egyenrangúságának megítélésével kapcsolatban a testnevelés mủveltségterületes hallgatók markánsabb, pozitívabb véleménnyel rendelkeznek, ugyanis a testnevelés (átlag: 1,33), illetve a többi müveltségterület (átlag: 1,75) között szignifikáns eltérés mutatkozott $(\mathrm{t}=-6,43 ; \mathrm{p}<0,001)$. Az eredmény nem meglepő, hiszen jellemzően mindenki kiáll a saját, választott szakja vagy müveltségterülete mellett.

Az életmódba beépülő testkulturális szokások testnevelés tantárgyon keresztüli kialakítását a müveltségterületes hallgatók sokkal inkább tantárgyi feladatnak tekintik, mint a többi hallgató. A negatív töltetü állításra adott válaszok összevetése jelentős eltérést mutatott. A válaszok átlaga a testnevelés müveltségterületesek esetében 3,94, a többi müveltségterületes esetében 3,61 volt $(\mathrm{t}=3,81 ; \mathrm{p}=0,00)$.

Említésre méltó különbséget találtunk még a két csoport között egyrészt azzal kapcsolatban, hogy a tanítók pozitív megítélését segíti, ha újszerü, élménynyújtó órákat alkalmaznak (testnevelés müveltségterület átlaga: 1,36; nem testnevelés müveltségterületes átlag: 1,46; $(\mathrm{t}=-$ 2,06; $\mathrm{p}=0,04)$ ). Másrészt pedig abban, hogy a tanítók minden gyermeknek képesek sikerélményt nyújtani a testnevelés órákon. A testnevelés (átlag: 1,33) és a nem testnevelés mủveltségterületesek (átlag: 1,44) véleménye között ez esetben nincs túl nagy különbség, de a szórás kis értéke miatt szignifikáns eltérést találtunk $(\mathrm{t}=-2,05 ; \mathrm{p}=0,041)$. Mindkét esetben a testnevelés műveltségterületesek viszonyultak pozitívabban e tevékenységekhez, amelyek szerepe egyébként kulcsfontosságú, hiszen meghatározhatja a tanulók testnevelés iránti attitüdjét. A változatos, újszerü tanórák hozzájárulnak a monotónia elkerüléséhez, melyek minden korosztálynál 
fontosak, de a kisiskolások esetében különösen lényeges elvárás, mert ezáltal könnyebben fenntartható a figyelmük, motiváltságuk. Az egyéni sikerélmény eredményes tanítói közvetítése szintén kulcsfontosságú pedagógiai módszer, jelentősége meghatározó lehet az egyének szintjén a mozgással kapcsolatos emóciókra, illetve a későbbi időszakra.

A mozgások tanításának, illetve tanulásának folyamatában módszertanilag nagyon fontos szerepe van a bemutatásnak, ezért a kérdőívben rákérdeztünk, hogy az új mozgások tanításánál mekkora szerepet tulajdonítanak a hallgatók a szemléltetés ezen formájának. A válaszadók egyértelműen a bemutatást támogató álláspontot képviselik (átlag: 1,47), a testnevelés műveltségterületesek (átlag: 1,33) pedig a többi műveltségterületeshez (átlag: 1,52) képest még határozottabban kiállnak a bemutatás módszere mellett. A hallgatók tehát alapvetően tisztában vannak a bemutatás módszerének jelentőségével.

\section{Összegzés}

A kérdőív 21 állítása közül 18 esetben nem találtunk szignifikáns véleménykülönbséget a nemek között, amely eredmény alapján megállapítható, hogy a hipotézis első fele igazolást nyert. A testnevelés és a nem testnevelés műveltségterületesek nézetei között jóval nagyobb mértékü különbségeket tapasztaltunk, ugyanis a 21 állításból 15 esetben a testnevelés müveltségterületesek rendelkeztek pozitívabb hozzáállással, amelyből hét szignifikánsnak bizonyult. Véleményünk szerint ez a mértékű különbség igazolja feltételezésünk második felét is, amelynek alapján a megfogalmazott hipotézist igazoltnak tekintettük.

A testnevelés műveltségterületesek kedvezőbb eredményei pozitívan igazolják vissza a képzésüket, hiszen magasabb óraszámban tanulják a testneveléssel kapcsolatos szakmai tantárgyakat, amelynek hatásai a legtöbb esetben megfigyelhetők voltak a válaszokban.

Amennyiben nemcsak a fentiekben közölt csoportok összehasonlítására, hanem a teljes minta eredményeire fókuszálunk, akkor azt a megállapítást tehetjük, hogy a tanítójelöltek kedvezően vélekednek a testnevelés tantárgyról, és képesek azonosulni alapvető céljaival is. Azonban nem hagyhatjuk figyelmen kívül a kutatás egyik legnagyobb tanulságát sem, mégpedig azt, hogy a tantárgy és a személyiségfejlesztéssel kapcsolatos kérdések területén kevésbé határozott véleményekkel, illetve nagyarányú döntésképtelenséggel találkoztunk. A 676 hallgatónak csak 59\%-a gondolja úgy, hogy a személyiségfejlesztés tantárgyi feladat, egy másik nyelvi kontextusban megfogalmazva a nevelésről pedig 52\%-uk nyilatkozott hasonlóan. Mindkét megfogalmazás esetében $25 \%$, illetve $24 \%$ volt a döntésképtelenek aránya. Az eredmények azt mutatják, 
hogy ezek a területek fejlesztésre szorulnak, vagyis markánsabban kell hangsúlyozni a hallgatók elméleti és gyakorlati képzésében a tantárgy személyiségfejlesztésre gyakorolt pozitív hatásait.

\section{BIBLIOGRÁFIA}

Domokos, Á. (2015). A relaxáció bevezetésének problematikája az oktatásban. In: Nagyházi, B. (szerk.): Képzés és Gyakorlat. LX. Képzés és Gyakorlat Nemzetközi Neveléstudományi Konferencia: Nevelés és tudomány, neveléstudomány a 21. században: Tanulmánykötet. pp. 363-371. Kaposvári Egyetem Pedagógiai Kar, Nyugat-magyarországi Egyetem Benedek Elek Pedagógiai Kar, [online] http://trainingandpractice.hu/sites/default/files/egyebkotetek/KE_9_Kepzes_es_Gyakorlat_TK_P001-457.pdf [2018. július 2.]

Kis, J. (1989). Attitüdök, jellemvonások alakítása, képességtermelés a testnevelésben és a sportban. A Testnevelési Föiskola közleményei, 9. évf. 2. sz. Melléklet, pp. 3-38.

Báthory, Z. (1989). Tanulói kötődések vizsgálata négy tanulói korosztály körében. Pedagógiai Szemle, 39. évf. 12. sz. pp. 1162-1172.

Báthory, Z. (2000). Tanulók, iskolák-különbségek. Egy differenciális tanuláselmélet vázlata. Budapest: Tankönyvkiadó.

Földesiné, Sz. Gy. (1982). A testnevelésórák iránti attitüdökről egy empirikus vizsgálat alapján I. Testnevelés tanitása, 18. évf. 4. sz. pp. 105-111.

Földesiné, Sz. Gy. (1982). A testnevelésórák iránti attitűdökről egy empirikus vizsgálat alapján II. Testnevelés tanitása, 18. évf. 5. sz. pp. 138-142.

Gombocz, J. (1999). Az iskolai testnevelés problémái az ezredfordulón. Kalokagathia, 37. évf. 1-2. sz. pp. 15-39.

Hamar, P. - Karsai, I. (2008). Az iskolai testnevelés affektív jellemzői 11-18 éves fiúk és lányok körében. Magyar pedagógia, 108. évf. 2. sz. pp. 135-147.

Jankovics, J. (1990). A tanulóifjúság testneveléssel és sporttal kapcsolatos attitűdjei. A Magyar Testnevelési Egyetem közleményei, 10. évf. 2. sz. pp. 31-63.

Oláh, Zs. - Makszin, I. (2005). A tanulók viszonyulása a testneveléshez és a testnevelési osztályzatokhoz. Magyar Sporttudományi Szemle, 6. évf. 21. sz. pp. 23-26. 


\section{ZOLTÁN KISS - ESZTER SZABÓ \\ THE APPROACH OF TEACHING CANDIDATES TO PHYSICAL EDUCATION REFLECTED IN A COMPARATIVE STUDY}

The attitude towards physical education of pedagogues who work as teachers may determine and influence the quality of teaching this subject. For this reason we examined the teaching candidates' attitude towards physical education as a subject from different angles, which might have an influence directly and indirectly on their future work - in the case of choosing this profession.

The structure of the research was based on an attitude-scale survey in which the students were asked to indicate the level of their agreement or disagreement with previously formulated statements. This pattern of the research was completed by 676 students in the teaching programme from 6 institutions, from each year and cultural domain within the faculty. From the answers it can be clearly stated that students consider physical education to be important, although in terms of professional-like questions they tend to be indecisive. The results were compared with respect to gender and cultural domain. The opinion of different genders showed great similarity, however the comparison of cultural domain seemed to have divergence, especially concerning those with physical education as their cultural domain.

The results draw attention to such quintessential phenomena that would be worth treating more emphatically regarding both theoretical and practical training. In order to provide students a background knowledge that contributes to success with regards to their work - also in the field of physical education -, a deliberate way of treating this previous information must be of crucial concern. 
